not properly addressed in rule-making and law-enforcement practice. The author has analyzed credit and billable relations in the countries of the European Union and has offered to carry out transformations, which can promote the improvement of legal regulation of the researched relations, in particular to create equal conditions for competition in the financial sector; to introduce special requirements in regard to capital, liquidity and other indicators of systemically important banks and other financial institutions; to improve the systems of regulation and supervision over the financial sector; to ensure further development of non-cash circulation and development of retail non-cash payments using electronic means of payment.

Keywords: settlement of accounts, payment transaction, legal relations, credit and billable relations, legal content of settlement relations, European Union.

DOI: 10.33766/2524-0323.92.93-104

УДК 343.352

В. О. Веретянніков, начальник навчально-методичного відділу, здобувач Луганського державного університету внутрішніх справ імені Е. О. Дідоренка (м. Сєвєродонецьк, Україна) e-mail: vladimirveretyannikov@gmail.com iDhttps:/ / orcid.org/ 0000-0001-7513-2292

\title{
ПРАВОЗАСТОСОВНЕ ТЛУМАЧЕННЯ ПРОВОКАЦІЇ КРИМІНАЛЬНОГО ПРАВОПОРУШЕННЯ В ПРАКТИЦІ ЄВРОПЕЙСЬКОГО СУДУ 3 ПРАВ ЛЮДИНИ
}

У статті проаналізовані вироблені практикою Європейського суду з прав людини основні підходи до визначення юридичного змісту та меж провокації кримінального правопорушення як неприпустимої поведінки з боку представників правоохоронних органів або інших осіб, яких правоохоронщі спонукають на провокаційну поведінку. Установлено, що така поведінка утворює порушення права особи на справедливий суд у контексті ч.1 ст. 6 Конвенщії про захист прав людини й основоположних свобод.

Також запропоновано авторське узагальнення критеріїв та ознак провокації кримінального правопорушення, які повинні враховуватися вітчизняними правоохоронними органами і судами в процесі як реалізації, так і юридичної оцінки різних форм контролю за вчиненням протиправного діяння.

Ключові слова: провокація, право на справедливий суд, співучасть у злочині, негласні слідчі (розшукові) дії, контроль за вчиненням злочину.

Постановка проблеми. «Давно сформованою позищією Свропейського Суду $\epsilon$ те, що суспільні інтереси не можуть обгрунтовувати використання доказів, отриманих у результаті поліцейської провокації, оскільки застосування таких доказів 3 самого початку піддасть обвинуваченого ризику позбутися справедливого судового розгляду» [1]. Ця позищія Свропейського суду з прав людини (далі - ССПЛабо Європейський Суд), висловлена 2016 року в справі «Баннікова проти Росіі» (п.34) певним чином орієнтує і чинну практику цього Суду, і національні суди державучасниць Конвенщії про захист прав людини й основоположних свобод 1950 р. (далі 
- Конвенція) на вироблення певних меж, до слова, не завжди чітких, у складній категорії кримінальних справ, пов' язаних із можливим зверненням до провокаційної поведінки з боку правоохоронців під час розслідування окремих видів злочинних діянь, що характеризуються високим ступенем латентності.

Справді, проблема провокації злочину є чутливою, невіддільно пов' язаною 3 морально-етичними засадами життєдіяльності суспільства і перебуває у світоглядній площині, передбачаючи пошук відповіді на складне питання: чи здатна благородна мета виправдати будь-які засоби, що використовуються для іï досягнення? Це є умовним наріжним каменем, що вже багато років турбує європейських правників, зокрема вітчизняних.

О. О. Дудоров небезпідставно зауважує, що, попри негативне ставлення (далі - ССПЛ) до провокаційної поведінки правоохоронців, яка полягає в підбурюванні осіб до вчинення злочинів (на цю обставину варто зважати з урахуванням ст. 17 Закону України «Про виконання рішень та застосування практики Європейського суду з прав людини»), питання допустимості провокації як методу протидії зокрема корупційним деліктам час від часу постає і в політикумі, і в професійному середовищі. Частково це пов'язується з ідеєю залучення до антикорупщійної діяльності інститутів громадянського суспільства, як чинник підвищення ефективності такої діяльності [2, с. 14-15].

Аналіз останніх досліджень і публікацій. Складна проблематика юридичної (матеріальної та процесуальної) оцінки провокаційної поведінки, у т. ч. в аспекті правозастосовної діяльності європейських та американських судових інституцій, вельми активно розробляється вітчизняними науковцями, серед яких: О. І. Альошина, П. П. Андрушко, М. Г. Арманов, О. Ф. Бантишев, Т. С. Батраченко, В. О. Глушков, Ю. В. Гродецький, О. М. Грудзур, О. О. Дудоров, О. В. Зайцев, Д. В. Каменський, О. О. Кваша, В. М. Киричко, М. І. Мельник, І. І. Митрофанов, В. В. Навроцька, В. О. Навроцький, Р. С. Орловський, М. І. Панов, С. О. Письменський, М. А. Погорецький, А. В. Савченко, А. А. Стрижевська, В. І. Тютюгін, О. В. Ус, М. І. Хавронюк. На сторінках періодичних фахових видань та в юридичних електронних ресурсах посилання на прогресивну практику ССПЛ зустрічаються регулярно, проте спостерігається певний брак комплексного, «покрокового» наукового аналізу відповідних рішень Свропейського Суду, поєднаного з висвітленням результатів його впливу на розвиток (корегування) вітчизняної правозастосовної практики в частині кваліфікацій діянь, учинених під впливом зовнішньої провокації.

Формулювання цілей. Ураховуючи зазначене, мета наукової статті полягає в критичному аналізі практики ЄСПЛ у частині інтерпретації провокаційної поведінки та їі кримінально-правових наслідків, а також в узагальненні, з урахуванням цього, критеріїв та ознак провокації до вчинення кримінального правопорушення, що повинні враховуватися українськими правоохоронними органами та судами в процесі реалізації та юридичної оцінки різних форм контролю за вчиненням протиправного діяння.

Виклад основного матеріалу. У реальному житті межа між правомірними оперативно-розшуковими заходами (передусім негласними слідчими діями), спрямованими на розслідування злочину, та діями, які de facto є провокацією на 
вчинення злочину, часто є занадто мінливою. У свойй практиці у відповідному напрямі кримінального правозастосування ЄСПЛ розробив критерії, які допомагають позначити таку межу й у кожному конкретному випадку відмежувати ситуації, коли органи слідства просто спостерігають за вчиненням злочину, від випадків, за яких уповноважені державою особи запустили «спусковий механізм» такого злочину [3].

Як справедливо зауважує М. В. Мазур, суддя Касаційного кримінального суду у складі Верховного Суду, нерідко в практиці касаційного суду, особливо в справах щодо отримання неправомірної вигоди або збуту наркотичних засобів, постає проблема провокації злочину. Суддя додає, що в разі, якщо йдеться про провокацію злочину, то, як правило, адвокати в касащійних скаргах і виступах посилаються на рішення ССПЛ від 5 лютого 2008 р. у справі «Раманаускас проти ЛитвИ», а прокурори - на рішення від 20 лютого 2018 р. у справі «Раманаускас проти Литви» (№ 2) [4].

Відповідно до сформованої ССПЛ позищії, наявність державного інтересу не можна використовувати як обгрунтування щодо використання доказів, отриманих у результаті поліцейської провокації, оскільки застосування таких доказів наражає обвинуваченого на ризик остаточно позбавитися справедливого судового розгляду; внутрішньодержавне законодавство не повинно дозволяти використання доказів, отриманих унаслідок підбурювання з боку державних агентів. В іншому випадку норми національного законодавства не відповідають принципу «справедливого судочинства» [5].

Наразі Свропейським Судом вироблена концепщія провокації, яка порушує пункт 1 статті 6 Конвенщії ${ }^{1}$, та, відповідно, $є$ відмінною від застосування законних оперативних методів попереднього розслідування. Судом визначено таке: тоді як застосування спеціальних методів розслідування, зокрема негласних, не може саме по собі порушувати право на справедливий судовий розгляд, небезпека поліцейської провокації в результаті таких заходів передбачає, що їх застосування повинно бути обмежене зрозумілими рамками (рішення ЄСПЛ від 5 лютого 2008 р. у справі «Раманаускас проти Литви» [6]).

Прецедентне право суду не забороняє посилатися на стадії розслідування кримінальної справи і у випадку, якщо дозволяє характер злочинної дії, на докази, отримані в результаті проведення співробітниками правоохоронних органів операцій під прикриттям (наприклад, рішення ССПЛ від 15 червня 1992 року у справі «Люді проти Швейцарії» [7]). Водночас застосування агентів під прикриттям повинно бути обмежене, співробітники поліції мають право діяти таємно, однак при цьому не повинні вдаватись до підбурювання (рішення ЄСПЛ від 9 червня 1998 року у справі «Тейксейра де Кастро проти Португалії» [8]).

ЄСПЛ під провокацією (поліцейською) розуміє ситуації, коли задіяні посадові особи, які є або співробітниками органів безпеки, або особами, що діють за їх

${ }^{1}$ У першому пункті згаданої статті («Право на справедливий суд») зазначено, зокрема, про те, що кожен має право на справедливий і публічний розгляд його справи упродовж розумного строку незалежним і безстороннім судом, встановленим законом, який встановить обгрунтованість будьякого висунутого проти нього кримінального обвинувачення. 
дорученням, не обмежують свої дії лише розслідуванням кримінальної справи по суті неявним способом, а впливають на суб'єкт з метою спровокувати його на скоєння злочину, який в іншому випадку не було би скоєно, задля того щоб зробити можливим виявлення злочину, тобто отримати докази та порушити кримінальну справу (згадане рішення ССПЛ у справі «Раманаускас проти Литви» від 5 лютого 2008 року [6]).

Причому, вирішуючи питання про те, чи було таке розслідування de facto неявним, ССПЛ повинен вивчити причини, які обумовили проведення оперативних дій. Суд повинен виходити з того, чи мали місце об'єктивні підозри того, що заявник задіяний у злочинній діяльності або схильний до вчинення злочину.

У справі «Таранекс проти Латвії» ССПЛ зазначив, що ключовим у досліджуваній категорії справ є питання про те, чи було би розглядуване в суді кримінальне правопорушення вчинене без зовнішнього втручання з боку представників органів влади. Суд послався на раніше вироблене ним правило про те, що провокація (підбурювання) з боку поліції відбувається в тому разі, коли уповноважені працівники правоохоронних органів або особи, які діють за їхніми вказівками, не обмежуються лише об' єктивним, незалежним розслідуванням злочинної діяльності за принципом «пасивної поведінки», а навпаки, чинять такий вплив на суб'єкта, що підбурює його до вчинення правопорушення, яке за інших обставин не було би вчинене, а також для того, щоб уможливити доведення обставин правопорушення в суді [9].

Щільно пов'язаним із критерієм об'єктивної підозри є питання щодо етапу, на якому уповноважені органи державної влади здійснюють оперативні заходи, тобто вони просто «приєднались» до здійснення кримінально-караного діяння, або, навпаки, спровокували його.

Критично розмірковуючи над проблемними питаннями кваліфікації провокації підкупу в порівняльному контексті, П. Д. Гуйван зауважує, що активні, нав' язливі пропозищії, вимоги, погрози в зовнішньо контрольованій ситуації $з$ метою обіцянки, надання або отримання предмета підкупу підозрюваним указують на спрямованість умислу на вчинення провокативного злочину. Саме такий підхід, додає автор, використовує у свойй практиці ССПЛ, визначаючи в конкретній справі той поріг, який відмежовує провокацію злочину від нормальної, правомірної діяльності слідчих та судових органів [10, с. 89].

У досліджуваному контексті варто звернутись до слушного зауваження О. О. Дудорова про те, що, враховуючи правові позищії ССПЛ (зокрема рішення у справах: «Тейксейра де Кастро проти Португалії» від 9 червня 1998 р.; «Калабро проти Італії» від 21 березня 2002 р.; «Г. А. Ваньян проти Російської Федерації» від 15 грудня 2005 р.; «Худобін проти Росії» від 26 жовтня 2006 р.; «Раманаускас проти Литви» від 5 лютого 2008 р.; «Мілінієне проти Литви» від 24 червня 2008 р.; «Банніков проти Росії від 4 листопада 2010 р.; «Носко і Нефедов проти Росії» від 30 жовтня 2014 р.; «Матановіч проти Хорватії» від 4 квітня 2017 р.; «Чохонелідзе про Грузії від 28 червня 2018 р. тощо), було вироблено усталений правозастосовний підхід, відповідно до якого в разі, якщо при провокації винний сам викликає в іншої особи намір вчинити злочин з метою їі викриття, то при проведенні правомірних 
заходів під контроль беруться вже наявні процеси, пов'язані 3 посяганням на об' єкт кримінально-правової охорони. Презюмується, що такі заходи не ініціюють злочинну поведінку особи, а навпаки, втручаються в уже наявну реалізацію злочинного наміру, засвідчуючи при цьому певні події та факти [2, с. 29-30].

Ураховуючи зазначене, не повинні визнаватися, наприклад, провокацією підкупу дії, вчинені з метою викриття того, хто вчиняє одержання неправомірної вигоди, коли ця особа вимагає неправомірну вигоду, а інша особа для викриття вимагача погоджується на задоволення цієї вимоги, а далі, уже з відома правоохоронних органів, передає неправомірну вигоду. Водночас не можуть розцінюватись як правомірні вчинені під час контролю за злочином пропозиція чи обіцянка неправомірної вигоди, оскільки такі дії ініціюють подальшу злочинну поведінку службової особи у формі прийняття такої пропозиції чи обіцянки.

De jure, відповідно до сформованої ЄСПЛ позищії, існування державного (суспільного) інтересу не можна використовувати для обгрунтування використання доказів, отриманих унаслідок поліцейської провокації, оскільки застосування таких доказів створює для обвинуваченого ризик бути позбавленим права на справедливий судовий розгляд із самого початку; національне законодавство не повинно авторизувати використання доказів, отриманих унаслідок підбурювання 3 боку державних агентів. У протилежному випадку відповідні законодавчі норми не відповідають принципу «справедливого судочинства».

Наразі згадані та деякі інші релевантні для цілей статті рішення європейської судової інстанщії вартують більш предметного аналізу: через призму правозастосовної практики ССПЛ вони орієнтують уже українського правозастосувача на правильне застосування матеріально-процесуальних положень, пов' язаних із визначенням меж недопустимої провокації кримінального правопорушення.

Європейський Суд установив у своїх рішеннях, що застосування спеціальних методів (тактик) розслідування, зокрема негласних, не може саме по собі порушувати право на справедливий судовий розгляд; небезпека поліцейської провокації в результаті таких заходів передбачає, що їх застосування повинно бути обмежене зрозумілими рамками [5].

Наразі релевантна практика ССПЛ оперує двома критеріями - матеріальним і процесуальним, створеними з метою відмежування провокащії, що порушує п.1 ст. 6 Конвенщії про захист прав людини й основоположних свобод, від допустимої поведінки при використанні законних таємних слідчих дій. У контексті матеріального критерію (англ. - substantive test of incitement) потрібно визначити, керуючись наявними у справі матеріалами, чи було би злочин вчинено без безпосереднього втручання правоохоронних органів, тобто чи було розслідування «пасивним».

Не менш важливим є процесуальний критерій (англ. - procedural test of incitement), покликаний визначити, яким чином національні суди розглядали заяву особи про здійснену щодо нього провокацію, що є частиною процедури розгляду скарги про агента-провокатора. ЄСПЛ вимагає, щоб процедура перевірки небезпідставної заяви про провокацію була змагальною, ретельною, вичерпною та остаточною. Суд також зазначив, що тягар доведення відсутності провокації покладається на сторону обвинувачення. 
До слова, ці критерії активно використовуються і в практищі ККС ВС. Зокрема, постановою ККС ВС у справі № 686/9761/16-к залишено без зміни виправдувальний вирок щодо особи, яка обвинувачувалася, окрім іншого, за ч. 3 ст. 369 КК України в наданні неправомірної вигоди службовій особі, котра обіймає відповідальну посаду, а саме прокурору. Верховний Суд визнав обгрунтованими висновки нижчих судів про недоведеність винуватості особи у зв'язку з наявністю ознак провокації злочину.

Рішення у справі «Раманаускас проти Литви» (№ 2) продемонструвало, що не кожна заява сторони захисту про провокацію злочину автоматично означає порушення ст. 6 Конвенщії та повинна закінчуватися виправдувальним вироком. У цій справі ЄСПЛ, оцінивши всі обставини, зробив висновок про те, що підбурення до вчинення правопорушення не відбулось, а тому подальше використання доказів, отриманих у ході кримінального провадження проти заявника, є такими, що не порушують положення п.1 ст. 6 Конвенщії [11].

Одноголосно з цією практикою нерідко Верховний Суд відмовляє в задоволенні відповідних касаційних скарг сторони захисту, з' ясувавши, що суди нижчих інстанцій відхилили доводи сторони захисту щодо провокації злочину після їх ретельної перевірки з наведенням відповідних переконливих мотивів у судовому рішенні.

У контексті вітчизняного правозастосування важливо звернути увагу на те, що у своєму рішенні в уже згаданій (першій) справі «Раманаускас проти Литви» (п.п. 54, 55, 60) ССПЛ зазначив: 1) використання доказів, отриманих унаслідок підбурювання з боку поліції, не можна виправдати суспільним інтересом, оскільки в такому випадку обвинувачений із самого початку може бути позбавлений права на справедливий судовий розгляд справи (п.54); 2) підбурювання з боку поліції має місце тоді, коли відповідні працівники правоохоронних органів або особи, які діють за їхніми вказівками, не обмежується розслідуванням в «пасивному» режимі, а з метою встановлення злочину, тобто отримання доказів і порушення кримінальної справи, впливають на суб'єкта, схиляючи його до вчинення злочину, який в іншому випадку не був би вчинений (п.55); 3) у разі, коли підсудний заявляє про підбурювання його до вчинення злочину, національний суд повинен ретельно перевірити матеріали кримінальної справи, оскільки з метою забезпечення права на справедливий судовий розгляд справи в розумінні п.1 ст. 6 Конвенщії про захист прав людини й основоположних свобод усі докази, отримані внаслідок підбурювання з боку поліції, повинні визнаватись недопустимими (п.60) [6]

У порівняльному режимі, аналізуючи вимоги українського законодавства в частині умовного тесту на «активність/пасивність» поведінки правоохоронців у процесі вчинення відомого їм кримінального правопорушення, то тут варто зауважити, що, відповідно до ч.1 ст. 24 Закону України «Про запобігання корупщії, особи, уповноважені на виконання функцій держави або місцевого самоврядування, прирівняні до них особи в разі надходження пропозищії щодо неправомірної вигоди або подарунка, незважаючи на приватні інтереси, зобов' язані невідкладно вжити таких заходів: 1) відмовитися від пропозиції; 2) за можливості ідентифікувати особу, яка зробила пропозицію; 3) залучити свідків, якщо це можливо, у т.ч. 
із числа співробітників; 4) письмово повідомити про пропозицію безпосереднього керівника (за наявності) або керівника відповідного органу, підприємства, установи, організації, спеціально уповноважених суб'єктів у сфері протидії корупції. Відповідь на питання про те, чи були перелічені дії вчинені уповноваженою особою, сприятиме аналізу правової ситуації на предмет наявності чи, навпаки, відсутності злочинної провокації.

У запропонованому в цій статті науковому дискурсі заслуговує на ретельне ознайомлення також рішення ЄСПЛ у справі «Акбай та інші проти Німеччини» від 15 жовтня 2020 р. Як випливає з обставин справи, чоловік першої заявнищі в цій справі, другий та третій заявники були засуджені за вчинення злочинів у сфері обігу наркотичних речовин за результатами проведеної операції у боротьбі з контрабандою [12].

Заявники вказували на порушення їхнього права на справедливий суд за п.1 ст. 6 Свропейської конвенції з прав людини, оскільки всі три були засуджені за злочини, на вчинення яких вони були спровоковані поліцією.

У своєму рішенні ССПЛ констатував порушення п.1 ст. 6 Конвенції за скаргами першого та другого заявників, однак не встановив порушення цього положення стосовно третього заявника.

Непряма провокащія описує ситуацію, за якої особа безпосередньо не контактує з працівниками поліції, які діють під прикриттям, проте залучається до вчинення правопорушення співучасником, якого безпосередньо спровокували органи поліції на вчинення злочину.

У своїй попередньо сформованій практиці ССПЛ установив, що особа може бути суб'єктом провокації також у разі коли вона не мала безпосереднього контакту з працівниками поліції, котрі діють під прикриттям, але була втягнута у вчинення злочину співучасником, який був прямо спровокований на вчинення злочину працівниками поліції [13].

Одна з ключових позицій ЄСПЛ у справі «Акбай та інші проти Німеччини» полягала в тому, що констатація провокації щодо одного співучасника не призводить до автоматичної констатації провокації щодо усіх інших учасників. Водночас критерії визначення непрямої провокації відрізняються від оцінки прямої провокації.

На підставі ретельного аналізу своєї попередньої усталеної практики Суд застосував розгорнутий тест для оцінки непрямої провокації, який грунтується на комплексному вирішенні декількох питань: (а) чи було передбачуваним для поліції те, що особа, яка безпосередньо схиляється до вчинення злочину, контактуватиме з іншими особами в процесі вчинення спільного злочину; (б) чи фактично скеровувалась (набувала змісту) діяльність цих осіб також поведінкою поліцейських; та (в) чи були ці особи визнані співучасниками злочину національними судами (п.117 рішення) [12].

Відповідні критерії набули розвитку з ознак правомірної прямої провокації 3 урахуванням похідної правової природи непрямої провокації.

Важливою є також та обставина, що відповідні критерії повинні аналізуватись у сукупності, що, власне, і було здійснено в цій справі. Зокрема, за першим 
критерієм судом було встановлено, що поліцейські усвідомлювали те, що особа, яка схилялась до вчинення злочину, контактуватиме з іншими особами у зв'язку зі вчиненням останнього. Щодо другого критерію, то суд установив таке: попри те, що відповідна протиправна діяльність, пов'язана з незаконним обігом наркотичних засобів, була фактично спровокована поліцією, у цій справі діяльність одного із співучасників (а саме третього заявника), не була спровокована поліцією, а навпаки, грунтувалась на інших обставинах. Нарешті, щодо третього критерію, то судом було встановлено, що третього заявника було визнано співучасником за відповідною нормою КК ФРН [3].

Отже, критерії так званої непрямої провокації, яка може бути визнаною такою, що відповідає вимогам Конвенщії навіть у тому випадку, якщо інші співучасники були неправомірно спровоковані на вчинення злочину, є оцінними. Ключовим у таких ситуаціях стає критерій, який дає відповідь на питання про наявність/відсутність в особи свободи волевиявлення, пов'язаної з протиправною поведінкою: якщо констатовано можливість вільного вибору поведінки, то непряма провокація відповідає вимогам Конвенщії про право на справедливий суд.

На останок варто звернути увагу на такий момент. Як було зазначено в попередньому абзаці, критерії непрямої провокації є оцінними. Те ж саме стосується і визначення критеріїв прямої провокації: ознайомлення з відповідною практикою ЄСПЛ уможливлює виокремлення двох ліній аргументащії pro et contra наявності провокації в діях правоохоронщів. Наявність лише загальних (неконкретизованих) критеріїв щодо визначення провокаційної поведінки, хіба що за винятком чіткої позищії ССПЛ про те, що наявність державного інтересу не можна використовувати для обгрунтування правомірності поліцейської провокащії, загалом є обгрунтованою, об'єктивно пов' язаною з виправданою абстрактністю норм національного кримінального законодавства. Принагідно варто згадати про практику Свропейського Суду, відповідно до якої визначеність закону не може бути абсолютною. Зокрема, у рішенні «Гешмен і Герруп проти Сполученого Королівства» Суд надав роз' яснення: хоча визначеність у законі надзвичайно бажана, ії забезпечення може призвести до надмірної «затверділості» (негнучкості), тоді як закон ніколи не повинен відставати від обставин, що змінюються. Ступінь чіткості національних законів, яка в жодному разі не може охопити всі непередбачувані обставини, значною мірою залежить від змісту певного документа, сфери, на яку поширюється закон, а також від кількості та статусу тих, кому він адресований [14; 15].

Висновки. Вивчення практики ССПЛ, присвяченої юридичній оцінщі проявів провокації кримінального правопорушення, спонукає висловити декілька узагальнювальних міркувань.

По-перше, було визначено, що ССПЛ шляхом активної правозастосовної практики в досліджуваному напрямі сформував усталену позицію про те, що провокаційні дії під час проведення негласних оперативно-розшукових заходів є порушенням права особи на справедливий суд у контексті ч.1 ст. 6 Конвенщії про захист прав людини й основоположних свобод, а також напрацював декілька критеріїв відмежування провокації від проявів правомірної слідчої діяльності. Водночас порівняння запровадженого в Україні матеріально-процесуального механізму 
виявлення та юридичного реагування на провокаційні дії представників органів влади (передусім у межах ст. 370 KK) із практикою Свропейського Суду вказує на існування низки прогалин у досліджуваному механізмі кримінально-правового регулювання.

Існуючі в правозастосуванні проблеми спонукають підтримати висловлену в юридичній літературі позицію про доцільність включення до розділу КК України «Злочини проти правосуддя» окремої статті про відповідальність за провокацію злочину як універсального кримінально-правового засобу протидії провокаційній поведінщі правоохоронщів, причому не лише в контексті протидії корупщійним правопорушенням.

По-друге, практика ССПЛ в частині визначення меж провокаційної поведінки оперує двома критеріями - матеріальним і процесуальним, створеними з метою відмежування провокації від допустимої поведінки під час використання негласних слідчих дій. У контексті матеріального критерію необхідно встановити, чи був би злочин вчинений за відсутності активного втручання правоохоронних органів; водночас процесуальний критерій покликаний детально визначити, у який спосіб національні суди розглядали заяву особи про здійснену щодо нього провокацію, що є частиною процедури розгляду скарги на дії «агента-провокатора».

По-третє, критичний аналіз практики ССПЛ в аспекті розмежування провокації від правомірних способів розслідування злочинів, які передбачають проникнення працівників правоохоронних органів у злочинні угрупування, свідчить про те, що такі критерії є сформульованими лише в загальних рисах, що є виправданим.

\section{Використані джерела:}

1. Bannikova v. Russia, no. 18757/06, ECHR 2016.

2. Дудоров О. О. Про перспективи законодавчого унормування провокаційної поведінки та їі правових наслідків. Вісник Асоиіаиії кримінального права Украӥни. 2020. № 2(14). C. 14-56. URL: http://vakp.nlu.edu.ua/article/view/217578/0. (дата звернення: 02.12.2020).

3. Бабанли Р., Тарасенко О. Критерії НЕПрямої провокації на вчинення злочину: розвиток практики Свропейського суду з прав людини у справі «Akbay and Others v. Germany». Судебно-юридическая газета. URL : https://sud.ua/ru/news/blog/182446-krite riyinepryamoyi-provokatsiyi-na-vchinennya-zlochinu-rozvitok-praktiki-yevropeyskogo-sudu-zprav-lyudini-u-spravi-akbay-and-others-v-germany?fbclid=IwAR3thANVnxS2nJj5zVbs YHliu zr FmIpqC2Laxvi- eC4OKXKO454xp5H4o4A. (дата звернення: 02.12.2020)

4. Провокація злочину: критерії ССПЛ та практика KKC BC. URL : https:// zib. com. ua/ua/143836-provokaciya_zlochinu_kriterii_espl_ta_praktika_kks_vs.html. (дата звернення: 02.12.2020).

5. Алданова К. Ю. Провокація злочину: практика Європейського суду з прав людини. URL : https://sud.ua/ru/news/blog/112137-provokatsiya-zlochinupraktika-yevrope yskogo sudu-z-prav-lyudini. (дата звернення: 02.12.2020).

6. Ramanauskas v. Lithuania, no.74420/01, ECHR 2008.

7. Lüdi v. Switzerland, no. 12433/86, ECHR 1992.

8. Teixeira De Castro v. Portugal, no. 44/1997/828/1034, ECHR 1998.

9. Taraneks v. Latvia, no. 3082/06, ECHR 2014. 
10. Гуйван П.Д. До питання про кваліфікацію провокації підкупу: європейський досвід. Вчені записки ТНУ імені В. І. Вернадського. Серія : юридичні науки. 2019. Том 30 (69). № 1. C. 87-93.

11. Ramanauskas v. Lithuania (No. 2), no. 55146/14, ECHR 2018.

12. Akbay and Others v. Germany, no. 40495/15, ECHR 2020.

13. Lalas v. Lithuania, no. 13109/04, ECHR 2011.

14. Hashman and Harrup v. The United Kingdom, no. 25594/94, ECHR 1999.

15. Богачова Л. Принцип правової визначеності в європейському і національному праві (змістовна характеристика). Теорія і практика правознавства. 2013. № 2. URL : http:/ / nbuv.gov.ua/UJRN/tipp_2013_2_74.pdf. (дата звернення: 02.12.2020)

\section{References:}

1. Bannikova v. Russia, no. 18757/06, ECHR 2016. [in English].

2. Dudorov, O. O. (2020). Pro perspektyvy zakonodavchoho unormuvannia provokatsiinoi povedinky ta yii pravovykh naslidkiv. Visnyk Asotsiatsii kryminalnoho prava Ukrainy - Herald of the Association of Criminal Law of Ukraine, 2(14), 14-56. URL : http://vakp.nlu.edu.ua/article/view/ 217578/0. [in Ukrainian].

3. Babanly, R., Tarasenko O. (2020). Kryterii nepriamoi provokatsii na vchynennia zlochynu: rozvytok praktyky Yevropeiskoho sudu z prav liudyny u spravi «Akbay and Others v. Germany». Sudebno-iurydycheskaia hazeta - Judicial-Legal Newspaper. URL : https://sud.ua/ru/ news/blog/182446-kriteriyi-nepryamoyi-provokatsiyi-na-vchinennya-zlochinu-rozvitok-prak tiki-yevropeyskogo-sudu-z-prav-lyudini-u-spravi-akbay-and-others-v-germany?fbclid=IwA R3thANVnxS2njj5zVbsYHliuzrFmIpqC2Laxvi-eC4OKXKO454xp5 H4o4A. [in Ukrainian].

4. Provokatsiia zlochynu: kryterii YeSPL ta praktyka KKS VS (2020). Закон $і$ бізнес - Law and Business. URL : https://zib.com.ua/ua/143836-provokaciya_zlochinu_kriterii_espl_ta_prakti ka_kks_vs.html. [in Ukrainian].

5. Aldanova, K. Yu. (2017). Provokatsiia zlochynu: praktyka Yevropeiskoho sudu z prav liudyny. Sudebno-iurydycheskaia hazeta - Judicial-Legal Newspaper. URL : https://sud.ua/ru/ news / blog/112137-provokatsiya-zlochinupraktika-yevropeyskogo-sudu-z-prav-lyudini. [in Ukrainian].

6. Ramanauskas v. Lithuania, no.74420/01, ECHR 2008. [in English].

7. Lüdi v. Switzerland, no. 12433/86, ECHR 1992. [in English].

8. Teixeira De Castro v. Portugal, no. 44/1997/828/1034, ECHR 1998. [in English].

9. Taraneks v. Latvia, no. 3082/06, ECHR 2014. [in English].

10. Huivan, P.D. (2019). Do pytannia pro kvalifikatsiiu provokatsii pidkupu: yevropeiskyi dosvid. Vcheni zapysky TNU imeni V.I. Vernadskoho. Seriia: yurydychni nauky - Scientific notes of Tavria National University named after V.I. Vernadsky. Series: Legal Sciences, Vol. 30(69), 1, 87-93 [in Ukrainian].

11. Ramanauskas v. Lithuania (No. 2), no. 55146/14, ECHR 2018. [in English].

12. Akbay and Others v. Germany, no. 40495/15, ECHR 2020. [in English].

13. Lalas v. Lithuania, no. 13109/04, ECHR 2011. [in English].

14. Hashman and Harrup v. The United Kingdom, no. 25594/94, ECHR 1999. [in English].

15. Bohachova, L. (2013). Pryntsyp pravovoi vyznachenosti v yevropeiskomu i natsionalnomu pravi (zmistovna kharakterystyka). Teoriia i praktyka pravoznavstva -Theory and Practice of Law, 2. URL: http://nbuv.gov.ua/UJRN/tipp_2013_2_74.pdf. [in Ukrainian]. 
Веретянников В. А., начальник учебно-методического отдела, соискатель Луганского государственного университета внутренних дел имени Э. А. Дидоренко (г. Северодонецк, Украина)

\section{ПРАВОПРИМЕНИТЕЛЬНОЕ ТОЛКОВАНИЕ ПРОВОКАЦИИ УГОЛОВНОГО ПРАВОНАРУШЕНИЯ В ПРАКТИКЕ ЕВРОПЕЙСКОГО СУДА ПО ПРАВАМ ЧЕЛОВЕКА}

В статье проанализированы выработанные практикой Европейского суда по правам человека основные подходы к определению юридического содержания и гранищ провокации уголовного преступления как недопустимого поведения со стороны представителейправоохранительных органов или других лиц, которых правоохранители побуждают на провокационное поведение. Установлено, что такие поведение образует нарушение права человека на справедливый суд в контексте ч.1 ст. 6 Конвенции о защите прав человека и основных свобод.

Также предложено авторское обобщение критериев и признаков провокации уголовного правонарушения, которые должны учитываться отечественными правоохранительными органами и судами в процессе как реализации, так и юридической оценки различных форм контроля за совершением противоправного деяния.

Ключевые слова: провокация, право на справедливый суд, соучастие в преступлении, негласные следственные (розыскные) действия, контроль за совершением преступления.

Veretiannikov V., Head of the Educational and Methodological Department, Degree seeker at Luhansk State University of Internal Affairs named after E. Didorenko (Sievierodonetsk, Ukraine)

\section{LEGAL INTERPRETATION OF THE CRIMINAL OFFENSE PROVOCATION IN THE PRACTICE OF THE EUROPEAN COURT OF HUMAN RIGHTS}

The article analyzes main approaches, developed by the practice of the European Court of Human Rights, to the definition of the legal content and boundaries of the provocation of a criminal offense as unacceptable behavior on the part of representatives of law enforcement agencies or other persons encouraged by law enforcement officers to provocative behavior. It has been established that such behavior constitutes violation of a person's right to a fair trial in the context of Part 1 of Art. 6 of the Convention for the Protection of Human Rights and Fundamental Freedoms. Also the author's generalization of the criteria and elements of provocation of a criminal offense, which should be taken into account by domestic law enforcement agencies and courts in the process of both implementation and legal assessment of various forms of control over the commission of a wrongful act has been proposed.

It has been determined that the ECHR defines provocation (by representatives of law enforcement agencies) as externally created situations, when officials are involved, who are either 
employees of the competent national authorities, or persons acting on their behalf, and who do not limit their actions merely to the essentially secret (unofficially) investigation of a criminal case, but directly influence the subject in order to provoke him to commit a crime, which would not have been committed under other circumstances, in order to make it possible to identify the crime, that is, to obtain evidence of illegal behavior and initiate criminal proecution.

Based on the results of a critical comparison of the material procedural mechanism introduced in Ukraine for identifying and legal response to provocative actions of representatives of the authorities with the established practice of the European Court, a conclusion has been made about the existence of a number of gaps in the investigated mechanism of criminal law regulation.

Keywords: provocation, right to a fair trial, complicity in a crime, covert investigative (search) actions, control over commission of a crime.

DOI: 10.33766/2524-0323.92.104-120 УДК 343.35

\author{
А. А. Вознюк, \\ доктор юридичних наук, професор, \\ завідувач наукової лабораторії з проблем \\ протидії злочинності ННI № 1 \\ Національної академії внутрішніх справ \\ (м. Київ, Україна) \\ e-mail: vaa.999999@gmail.com \\ iDttps:/ / orcid.org/0000-0002-3352-5626
}

\title{
ДЕКЛАРУВАННЯ НЕДОСТОВІРНОЇ ІНФОРМАЩЇ ТА УМИСНЕ НЕПОДАННЯ ДЕКЛАРАЩЇ: НОВІ МОДЕЛІ ЗАБОРОННИХ КРИМІНАЛЬНО-ПРАВОВИХ НОРМ
}

У статті проаналізовано переваги та недоліки сучасних моделей підстав відповідальності за декларування недостовірної інформації та умисне неподання декларації кримінально-правової, адміністративно-правової та змішаної.

Зроблено висновок, що нові підстави відповідальності за декларування недостовірної інформації та неподання декларації, а також пропозиції щодо них, висловлені у відповідних законопроєктах, мають недоліки, пов'язані з наявністю підгрунтя для визнання неконституційними нових заборонних кримінально-правових норм, їх санкціями, формами вини, порогом кримінальної відповідальності за декларування недосто-вірної інформації, конструкцією "неподання декларації" тощо.

Сформульовано рекомендації для практики застосування ст. 366-2 та 366-3 Кримінального кодексу України, а також надано пропозищії щодо їх удосконалення.

Ключові слова: декларування недостовірної інформації; неподання декларації; декларація особи, уповноваженої на виконання функцій держави або місцевого самоврядування; декларація доходів; суб'єкт декларування; корупщія; неконституційність.

Постановка проблеми. 27 жовтня 2020 року відбувся потужний удар по механізму протидії корупції в Україні: Конституційний Суд України (далі - КСУ) прийняв рішення, яке призвело до часткової «паралізації» роботи НАЗК та «зни-

(C) Вознюк А. А., 2020 